\title{
The Full Expression of Fasting-Induced Torpor Requires $\beta 3$-Adrenergic Receptor Signaling
}

\author{
Steven J. Swoap, ${ }^{1}$ Margaret J. Gutilla, ${ }^{1}$ L. Cameron Liles, ${ }^{2}$ Ross 0. Smith, ${ }^{1}$ and David Weinshenker ${ }^{2}$ \\ ${ }^{1}$ Department of Biology, Williams College, Williamstown, Massachusetts 01267 and ${ }^{2}$ Department of Human Genetics, Emory University School of Medicine, \\ Atlanta, Georgia 30322
}

Torpor, a controlled rapid drop in metabolic rate and body temperature $\left(T_{\mathrm{b}}\right)$, is a hypometabolic adaptation to stressful environmental conditions, which occurs in many small mammals, marsupials, and birds. To date, signaling pathways required for torpor have not been identified. We examined the role of the sympathetic nervous system (SNS) in mediating the torpor adaptation to fasting by telemetrically monitoring the $T_{\mathrm{b}}$ of dopamine $\beta$-hydroxylase knock-out $(D b h-/-)$ mice, which lack the ability to produce the SNS transmitters, norepinephrine (NE), and epinephrine. Control $(D b h+/-)$ mice readily reduced serum leptin levels and entered torpor after a fast in a cool environment. In contrast, $D b h-/-$ mice failed to reduce serum leptin and enter torpor under fasting conditions, whereas restoration of peripheral but not central NE lowered serum leptin levels and rescued the torpor response. Torpor was expressed in fasted $D b h-/-$ mice immediately after administration of either the nonselective $\beta$-adrenergic receptor agonist isoproterenol or the $\beta 3$ adrenergic receptor (AR)-specific agonist CL 316243 [disodium (RR)-5-[2-[[2-(3-chlorophenyl)-2-hydroxyethyl]-amino]propyl]-1,3benzodioxazole-2,2-dicarboxylate], but not after administration of $\beta 1, \beta 2$, or $\alpha 1$ agonists. Importantly, the $\beta 3$-specific antagonist SR 59230A [3-(2-ethylphenoxy)-1-[(1,S)-1,2,3,4-tetrahydronapth-1-ylamino]-2S-2-propanol oxalate] severely blunted fasting-induced torpor in control mice, whereas other AR antagonists were ineffective. These results define a critical role of peripheral SNS activity at $\beta 3$-AR-containing tissues in the torpor adaptation to limited energy availability and cool ambient temperature.

Key words: adipose; $\beta$-adrenergic receptor; norepinephrine; knock-out mice; leptin; sympathetic nervous system; fasting

\section{Introduction}

The scarcity of food in a cool environment can be very difficult for a small mammal. Some small endotherms have the ability to hibernate, using multiday bouts of lowered body temperature $\left(T_{\mathrm{b}}\right)$, as low as $5^{\circ} \mathrm{C}$, that are separated by brief arousal periods (Lyman et al., 1982; Heldmaier et al., 1993; Geiser and Ruf, 1995; Geiser, 2004). Other species, including Mus musculus, exhibit a shallower minimum $T_{\mathrm{b}}\left(17-31^{\circ} \mathrm{C}\right)$ with bouts of shorter duration, typically ranging from 2 to $20 \mathrm{~h}$ (Hudson and Scott, 1979; Webb et al., 1982; Himms-Hagen, 1985a; Swoap, 2001; Bae et al., 2003; Bouthegourd et al., 2004). The regulation of $T_{\mathrm{b}}$ is maintained during torpor and not merely a function of heat lost to the environment after thermoregulation has been abandoned (Carey et al., 2003).

Daily caloric restriction, or even just a single overnight fast, can initiate a torpor bout in mice as long as the ambient temperature $\left(T_{\mathrm{a}}\right)$ is cool (Hudson and Scott, 1979; Webb et al., 1982; Himms-Hagen, 1985a; Gavrilova et al., 1999). Despite the extensive body of evidence characterizing hibernation and torpor

Received Sept. 2, 2005; revised Nov. 3, 2005; accepted Nov. 4, 2005.

This work was supported by National Science Foundation Grant IBN 9984170 (S.J.S.) and in part by a Howard Hughes Medical Institute grant to Williams College. We thank Sumitomo Pharmaceuticals (Osaka, Japan) for their generous donation of L-threo-3,4-dihydroxyphenyserine.

Correspondence should be addressed to Steven J. Swoap, Department of Biology, Williams College, Williamstown, MA 01267. E-mail: sswoap@williams.edu.

D0I:10.1523/JNEUROSCI.3721-05.2006

Copyright $\odot 2006$ Society for Neuroscience $\quad$ 0270-6474/06/260241-05\$15.00/0
(Wang and Hudson, 1978; Lyman et al., 1982), proximal signals that send an animal into, or arouse an animal from, a bout of torpor have yet to be identified. One of the signals that plays a central role in energy sensing is leptin, a hormone that is produced and secreted by white adipose tissue (WAT) and conveys information about peripheral fat stores to the hypothalamus (Flier, 1998). Leptin has been shown to blunt the depth of torpor, presumably because it increases metabolic rate, and ob/ob mice, which lack the leptin gene, enter torpor much more deeply and readily than wild-type mice (Döring et al., 1998; Geiser et al., 1998; Gavrilova et al., 1999; Freeman et al., 2004).

Heat is generated, in part, through nonshivering thermogenesis (NST). NST is stimulated primarily through activation of brown fat by the sympathetic nervous system (SNS). To determine whether recovery from a torpor bout requires this pathway, we used dopamine $\beta$-hydroxylase knock-out (Dbh-/-) mice, which lack the ability to synthesize the two primary neurotransmitters in the SNS, norepinephrine (NE) and epinephrine (Epi) (Thomas et al., 1995, 1998). Surprisingly, we found that these mice failed to enter torpor. Using a battery of agonist and antagonists for the adrenergic receptors (ARs), we found that torpor requires activation of the $\beta 3-\mathrm{AR}$, most likely in WAT.

\section{Materials and Methods}

Animals and pharmacological agents. All mice used were 2-3 months of age. Female $D b h-/-$ mice and their littermate controls, $D b h+/-$ mice, were bred and raised at Emory University and shipped to Williams College for physiological assessment. $D b h+/-$ mice were used as the con- 
trols because they have normal NE and Epi levels and are indistinguishable from wild-type mice for all aspects of behavior and physiology tested (Thomas et al., 1998; Murchison et al., 2004; Swoap et al., 2004). NIH Swiss and C57BL/6J mice were purchased from Harlan Sprague Dawley (Indianapolis, IN). Animals were maintained on a reverse $12 \mathrm{~h}$ light/dark cycle (lights on at 11:00 P.M., lights off at 11:00 A.M.). All animal studies were approved by the Williams College Institutional Animal Care and Use Committee. All pharmacological agents were purchased from Sigma (St. Louis, MO) with the exception of L-threo-3,4-dihydroxyphenyserine (DOPS), which was kindly provided by Sumitomo Pharmaceuticals (Osaka, Japan).

Implantation of temperature telemeters. Mice were anesthetized initially with $5 \%$ isoflurane in an oxygen stream, and maintained on $1-2 \%$ isoflurane. Mice were kept on a heating pad $\left(38^{\circ} \mathrm{C}\right)$ throughout implantation of the body temperature $\left(T_{\mathrm{b}}\right)$ telemeter (TA10TAF20; Data Sciences International, Arden Hills, MN) into the peritoneal cavity. Mice were maintained on a heating pad for $48 \mathrm{~h}$ after the surgery and then housed individually at $28-30^{\circ} \mathrm{C}$.

Fasting and pharmacology. After 1 week of recovery, mice were moved from the $28-30^{\circ} \mathrm{C}$ room into temperature-controlled $\left(20 \pm 0.25^{\circ} \mathrm{C}\right)$ custom-built cages containing telemetry receivers. Data from the $T_{\mathrm{b}}$ telemeters were recorded in $1 \mathrm{~s}$ streams at $500 \mathrm{~Hz}$ once per minute. In some instances, the rate of change of $T_{\mathrm{b}}$ was calculated over a $24 \mathrm{~h}$ period using a 30 min sliding window [i.e., $\left(T_{\mathrm{b} \text { at } t=0 \min }-T_{\mathrm{b} \text { at } t=30 \mathrm{~min}}\right) / 30 \mathrm{~min}$ ]. The maximum rate of heat loss was then generated from this data set. The mice were allowed to acclimate to $20^{\circ} \mathrm{C}$ housing for $2 \mathrm{~d}$. Data collected from the third $24 \mathrm{~h}$ period of $20^{\circ} \mathrm{C}$ housing was considered the "fed" period. Mice were then fasted at the onset of the dark cycle, when mice typically initiate food consumption. Mice were allowed ad libitum access to water throughout all experiments. DOPS-treated $D b h-/-$ mice received three subcutaneous injections at $1 \mathrm{~g} / \mathrm{kg}$ of body weight $(24 \mathrm{~h}$ preceding the fast, $12 \mathrm{~h}$ preceding the fast, and at the onset of the fast). DOPS was put into solution at $20 \mathrm{mg} / \mathrm{ml}$ containing $2 \mathrm{mg} / \mathrm{ml}$ vitamin C. Some $\mathrm{Dbh}-/-$ mice received three subcutaneous injections of a solution containing $1 \mathrm{~g}$ of DOPS $/ \mathrm{kg}$ and $0.25 \mathrm{mg}$ of benzerazide $/ \mathrm{kg}$, three times at the same times indicated for DOPS treatment. Agonists/antagonists of the adrenergic receptors were dissolved in PBS, unless otherwise noted, and administered intraperitoneally $4.5 \mathrm{~h}$ after fast in $0.1 \mathrm{cc}$ of solution. Dosages used were as follows (in $\mathrm{mg} / \mathrm{kg}$ ): 1 phenylephrine, 10 isoproterenol, 1 dobutamine, 2.5 salbutamol, 1 disodium $(R R)$-5-[2-[[2-(3-chlorophenyl)-2-hydroxyethyl]-amino] propyl]-1,3-benzodioxazole-2,2-dicarboxylate (CL 316243), 1 prasozin in 3\% DMSO, 1 atenolol, 1 erythro-1-(7methylindan-4-yloxy)-3-(isopropylamino)-but an-2-ol (ICI 118,511), and 1 3-(2-ethylphenoxy)-1-[(1,S)-1,2,3,4-tetrahydronapth-1-ylamino]-2S-2propanol oxalate (SR 59230A) in 3\% DMSO.

Serum collection and analysis. Serum was collected from a new set of fed and fasted $D b h+/-$ and $D b h-/-$ mice $5.5 \mathrm{~h}$ after initiation of the fast. A commercially available kit was used to analyze serum leptin (Linco Research, St. Charles, MO).

Statistics. Data are reported as mean and SE. After ANOVA, Student's $t$ tests were used to compare between genotypes, and paired $t$ tests were used to compare $D b h-/-$ before and after pharmacological treatment. The 0.05 level of confidence was accepted for statistical significance.

\section{Results}

Dbh-/- mice fail to enter torpor

Because brown fat thermogenesis can defend $T_{\mathrm{b}}$ in mice exposed to cold (Collins and Surwit, 2001; Nicholls, 2001), we hypothesized that the rapid rise in $T_{\mathrm{b}}$ during arousal from fasting-induced torpor requires activation of brown fat thermogenesis. To test this idea, we telemetrically monitored the $T_{\mathrm{b}}$ of $D b h-/-$ mice $(n=8)$ in response to fasting. We were unable to test the hypothesis because not one $D b h-/-$ mice initiated torpor in response to fasting (Fig. $1 A, B$ ). However, every fasted $D b h+/-$ littermate control mouse $(n=8)$ readily entered torpor (Fig. $1 A)$. The minimum $T_{\mathrm{b}}$ of $D b h+/-$ mice during the torpor bout reached $22.6 \pm 0.4^{\circ} \mathrm{C}$, whereas $D b h-/-$ reached a minimum $T_{\mathrm{b}}$ at the end of the $24 \mathrm{~h}$ period of $31.1 \pm 0.4^{\circ} \mathrm{C}$. Although this hypother-

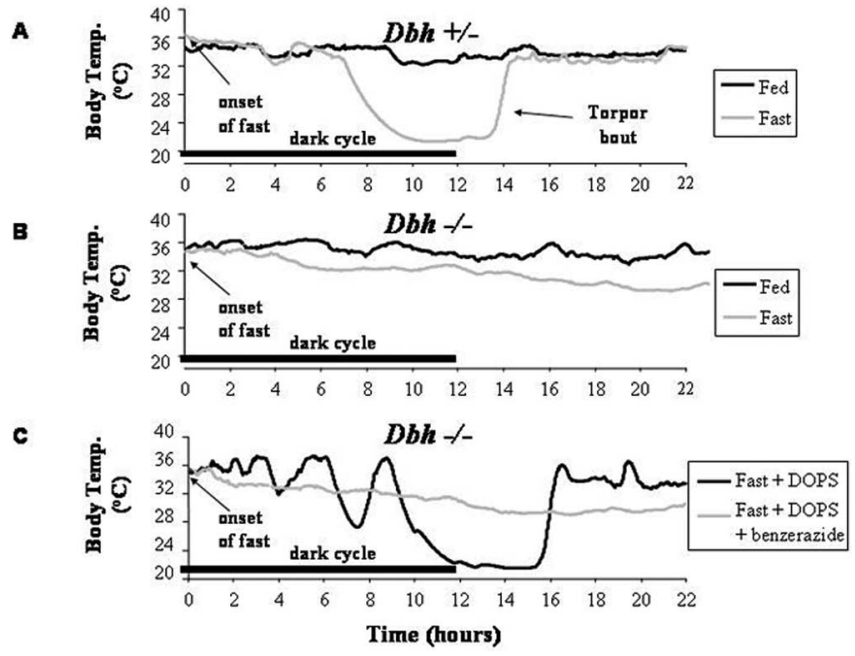

Figure 1. Dbh-/- mice do not initiate torpor in response to fasting. $A, A$ typical temperature tracing in a fed $D b h+/-$ mouse and the same mouse fasted at the onset of the dark cycle. $\boldsymbol{B}$, Typical temperature tracings from a Dbh-/- mouse before and during a fast. $\boldsymbol{C}$, Typical temperature tracings from a Dbh $-/-$ mouse treated with DOPS or DOPS plus benzerazide.

mic $T_{\mathrm{b}}$ of fasted $D b h-/-$ may at first glance suggest a torpor bout, none of these mice exhibited the distinctive steep drop in $T_{\mathrm{b}}$ of torpor (Fig. 1). To assess this aspect of torpor, we calculated the maximum rate of $T_{\mathrm{b}}$ drop over a $30 \mathrm{~min}$ period within the fed or fasted state. $D b h+/-$ that entered torpor lost $T_{\mathrm{b}}$ at a significantly higher rate as in the fed state $\left(0.158 \pm 0.004\right.$ vs $0.077 \pm 0.004^{\circ} \mathrm{C}$ per minute, respectively). $\mathrm{Dbh}-/-$ mice, however, showed no significant difference in the maximum drop of $T_{\mathrm{b}}$ in fed or fasted states $\left(0.085 \pm 0.004\right.$ vs $0.072 \pm 0.005^{\circ} \mathrm{C}$ per minute, respectively).

\section{Peripheral, but not central, restoration of norepinephrine rescues the torpor phenotype}

To determine whether the torpor phenotype can be rescued in the Dbh $-/-$ mice, we implanted another nine $D b h-/-$ mice with $T_{\mathrm{b}}$ telemeters and administered the synthetic amino acid DOPS, which restores NE levels through the action of aromatic L-amino acid decarboxylase (AAD) to the brain and sympathetic nerves, but not to adrenal tissue (Thomas et al., 1998). When fasted, eight of the nine DOPS-treated $D b h-/-$ mice entered torpor normally (Fig. $1 C$ ), with a maximum rate of $T_{\mathrm{b}}$ drop of the entire group of $0.147 \pm 0.007^{\circ} \mathrm{C}$ per minute. This suggests that $D b h-/-$ mice did not enter torpor because they specifically lack NE. To determine whether central or peripheral NE is required for the torpor, we administered DOPS alone $(n=11)$ or DOPS with benzerazide $(n=12)$, an inhibitor of AAD that does not cross the bloodbrain barrier and restricts NE restoration to the brains of Dbh-/- mice (Murchison et al., 2004). As seen previously, DOPS rescued the torpor phenotype in 10 of the 11 mice (maximum rate of $T_{\mathrm{b}}$ drop, $0.163 \pm 0.006^{\circ} \mathrm{C}$ per minute). However, none of the DOPS plus benzerazide-treated $\mathrm{Dbh}-/-$ mice initiated torpor (for a typical tracing, see Fig. $1 C$ ). The maximum rate of $T_{\mathrm{b}}$ drop in this group was $0.045 \pm 0.003^{\circ} \mathrm{C}$ per minute. Thus, sympathetic $\mathrm{NE}$ is specifically required for the ability to enter torpor.

\section{Torpor in fasted $\mathrm{Dbh}-/-$ mice requires activation of the $\boldsymbol{\beta} 3$-adrenergic receptor}

To determine which class of AR mediates the regulation of torpor by NE, $D b h-/-$ mice $(n=10)$ were fasted and admin- 
A

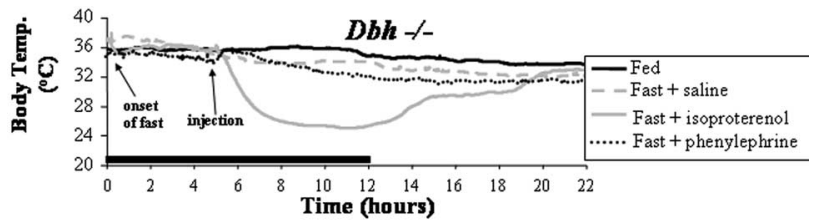

$\mathbf{B}$

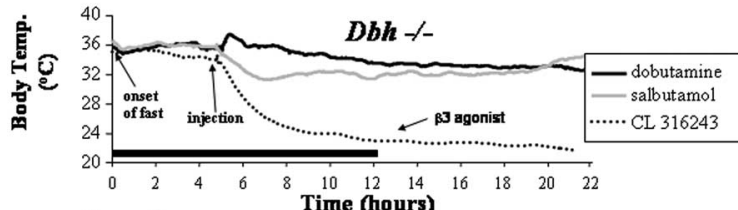

c

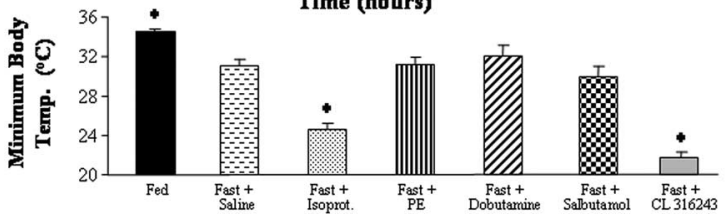

Figure 2. Administration of a nonspecific $\beta$-AR agonist or a $\beta 3-A R$-specific agonist allows for the initiation of torpor in $D b h-/-$ mice. $A$, The average $T_{\mathrm{b}}$ from all of the $D b h-/-$ mice was collected once per minute for $22 \mathrm{~h}$. Intraperitoneal injection of saline, isoproterenol (a nonspecific $\beta$-AR agonist), or phenylephrine (an $\alpha 1$-AR agonist) occurred $4.5 \mathrm{~h}$ after the initiation of the fast. $\boldsymbol{B}$, Average $T_{\mathrm{b}}$ from the $D b h-/-$ mice injected with dobutamine ( $\beta 1$-specific agonist), salbutamol ( $\beta 2$-specific agonist), or CL 316243 ( $\beta 3$-specific agonist). $C$, Minimum $T_{\mathrm{b}}$ over the $22 \mathrm{~h}$ period. ${ }^{*} p<0.05$ versus fasting with saline injection. Error bars indicate SE.

istered subtype-selective adrenergic agonists $4.5 \mathrm{~h}$ after the initiation of fasting. Activation of $\alpha 1$-ARs with phenylephrine during the fast had no effect on the $T_{\mathrm{b}}$ of $D b h-/-$ mice. After $7 \mathrm{~d}$ of recovery from the fast at $30^{\circ} \mathrm{C}$, the same animals were rehoused at $20^{\circ} \mathrm{C}$ for 3 more days, fasted, and injected $4.5 \mathrm{~h}$ into the fast with isoproterenol, a nonspecific $\beta$-AR agonist. This resulted in an immediate drop in $T_{\mathrm{b}}$, indicative of torpor in all 10 mice (minimum $T_{\mathrm{b}}$ was $24.6 \pm 0.7^{\circ} \mathrm{C}$; maximum rate of $T_{\mathrm{b}}$ drop was $0.140 \pm 0.006^{\circ} \mathrm{C}$ per minute) (Fig. $2 \mathrm{~A}$ ). After another $7 \mathrm{~d}$ recovery period at $30^{\circ} \mathrm{C}$, and $3 \mathrm{~d}$ at $20^{\circ} \mathrm{C}$, these same mice were fasted and administered saline, which had no effect on the $T_{\mathrm{b}}$ of these mice (Fig. 2).

To determine which subtype of the $\beta$-ARs was responsible for mediating the torpor response, a new cohort of nine $D b h-/-$ mice were taken through the following protocol: fasting with the $\beta 1$-AR agonist dobutamine; $10 \mathrm{~d}$ recovery period; fasting with the $\beta 2$-AR agonist salbutamol; $10 \mathrm{~d}$ recovery period; fasting with the $\beta 3-A R$ agonist CL 316243. Torpor was not observed in any of the fasted $D b h-/-$ mice injected with either dobutamine or salbutamol. Only activation of the $\beta 3-\mathrm{AR}$ in fasted $\mathrm{Dbh}-/-$ mice permitted the expression of torpor in all nine mice within minutes of the injection, from which the mice did not spontaneously recover (minimum $T_{\mathrm{b}}$ was $21.8 \pm 0.5^{\circ} \mathrm{C}$; maximum rate of $T_{\mathrm{b}}$ drop was $0.140 \pm 0.006^{\circ} \mathrm{C}$ per minute) (Fig. $2 B$ ).

\section{Blocking the $\beta 3$ adrenergic receptor blunts torpor in \\ Dbh+/- mice}

To determine whether the $\beta 3$ pathway is important for torpor in normal mice, $D b h+/-$ mice $(n=24)$ were fasted and administered saline. After a $10 \mathrm{~d}$ recovery, these mice were fasted again and administered either the $\alpha 1$ antagonist prazosin $(n=$ $6)$, the $\beta 1$ antagonist atenolol $(n=6)$, the $\beta 2$ antagonist ICI $118,511(n=6)$, or the $\beta 3$ antagonist SR 59230A $(n=6)$. Blocking the $\beta 3-\mathrm{AR}$, and only this subtype, severely blunted fasting-induced torpor (Fig. 3). The length of the torpor bout, as defined as the amount of time spent at a $T_{\mathrm{b}}<31^{\circ} \mathrm{C}$ (Hudson and Scott, 1979), was much shorter when mice were treated
A
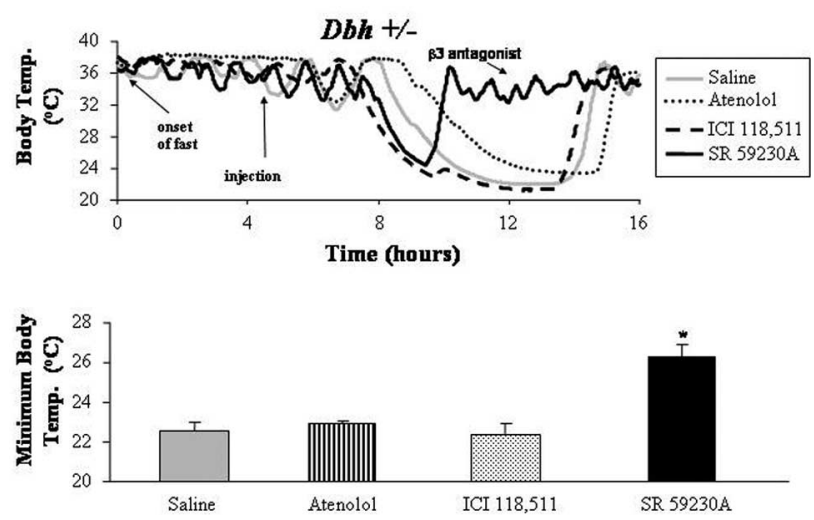

Figure 3. Administration of a $\beta 3$-specific AR antagonist blunts the depth of torpor. $\boldsymbol{A}$, $D b h+/-$ mice were fasted at the onset of the dark cycle and injected $4.5 \mathrm{~h}$ after the initiation of the fast with a $\beta 1$ antagonist (atenolol), a $\beta 2$ antagonist (ICl 118,511), or a $\beta 3$ antagonist (SR 59230A). Data shown are from the same animal under each of the conditions. $\boldsymbol{B}$, Minimum $T_{\mathrm{b}}$ during each fast. ${ }^{*} p<0.05$ versus saline injection.

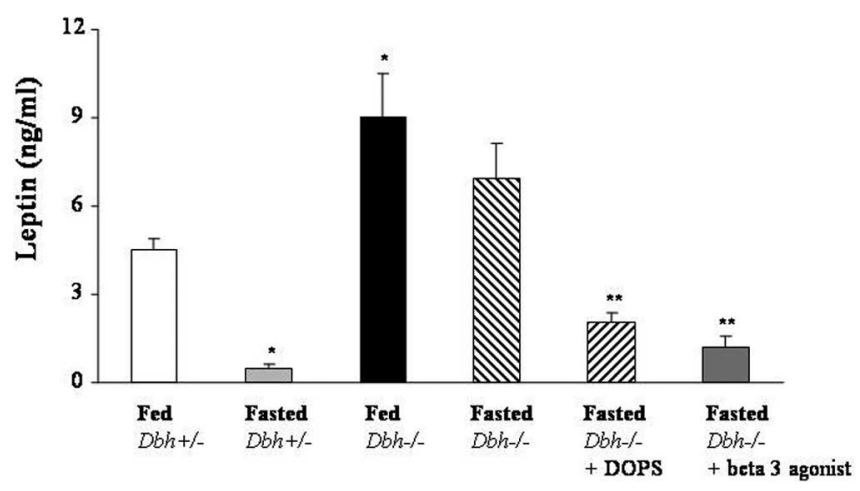

Figure 4. Serum leptin was measured in fed $D b h+/-$, fed $D b h-/-$, fasted $D b h+/-$, fasted $D b h-/-$, and fasted $D b h-/-$ mice injected with the $\beta 3$ agonist CL 316243. Serum was collected $5.5 \mathrm{~h}$ after the initiation of the fast. DOPS was injected three times: $24 \mathrm{~h}$ prefast, $12 \mathrm{~h}$ prefast, and at the initiation of the fast. CL 316243 was injected into mice $4.5 \mathrm{~h}$ after the initiation of the fast. ${ }^{*} p<0.05$ versus fed $D b h+/-$; $^{* *} p<0.05$ versus fasted $D b h-/-$.

with the $\beta 3$ antagonist as compared with treated with vehicle (111.6 \pm 12.6 vs $334.5 \pm 6.8 \mathrm{~min}$, respectively). A 10-fold higher dose $(10 \mathrm{mg} / \mathrm{kg})$ of SR58230A in a new set of seven $\mathrm{Dbh}+/-$ mice did not further blunt the torpor response, as all entered abbreviated bouts of torpor (minimum $T_{\mathrm{b}}=25.9 \pm$ 1.5; time in torpor, $122.1 \pm 32.5 \mathrm{~min}$ ). This suggests that the residual torpor response in SR 59230A-treated mice is mediated by a different pathway. Two wild-type mouse strains, NIH Swiss $(n=5)$ and C57BL6/J $(n=6)$ entered torpor normally after receiving SR 59230A but exhibited significantly shallower bouts of torpor than when administered vehicle (26.9 \pm 0.8 vs $21.3 \pm 0.5^{\circ} \mathrm{C}$, respectively).

Leptin, torpor, and $\mathrm{Dbh}-/-$ mice

To explore the possibility that an inability to decrease circulating leptin prevents $\mathrm{Dbh}-/-$ mice from entering torpor, leptin was measure from serum collected $5.5 \mathrm{~h}$ after the initiation of a fast, just before entrance into torpor for control animals. In $D b h+/-$ mice ( $n=7$ per group), fasting lowered serum leptin (Fig. 4 ), as has been observed previously (Frederich et al., 1995). Fed Dbh-/- mice $(n=5)$ were hyperleptinemic, suggesting that normal mice have a chronic inhibition of leptin release that is mediated through the SNS. After fasting, serum leptin failed to 
appropriately fall in $D b h-/-$ mice $(n=7)$. Treatment of Dbh $-/-$ mice with DOPS $(n=6)$, which allows for a normal bout of fasting-induced torpor (Fig. 1), caused a significant drop in circulating leptin, mimicking that of fasted $D b h+/-$ mice (Fig. 4). Similarly, injection of the $\beta 3$-AR agonist $1 \mathrm{~h}$ before serum collection in fasted $\mathrm{Dbh}-/-$ mice $(n=7)$ caused a dramatic fall in serum leptin.

\section{Discussion}

The data presented herein strongly support a critical role of the peripheral SNS activity at the $\beta 3$-AR in the torpor adaptation of mice to limited energy availability and cool ambient temperature. All wild-type mice we tested initiated a bout of torpor in response to fasting in a cool environment (ambient temperature, $<20^{\circ} \mathrm{C}$ ). We found that $\mathrm{Dbh}-/-$ mice failed to enter torpor under such conditions. In contrast to the controlled and well regulated bout of hypothermia in wild-type mice, the $D b h-/-$ mice appeared to enter a hypothermic state in a slow, uncontrolled and unregulated manner. Dbh-/mice with restored peripheral NE by acute treatment with DOPS or a $\beta 3$ agonist acquired the ability to enter torpor, suggesting that their failure to enter torpor with fasting is not because of developmental differences and/or compensatory changes. These mice are simply missing the transmitter that allows for the initiation of the torpor response.

Many animals in the wild will enter torpor bouts spontaneously, often in preparation for an anticipated energetic stress (Speakman and Rowland, 1999; Geiser, 2004). However, mice require two environmental insults: (1) relatively cool ambient temperature and (2) caloric deprivation (Himms-Hagen, 1985a). Cool ambient temperature engages thermogenic pathways for the production of heat to offset heat loss. As such, cool ambient temperature activates the SNS particularly to thermogenic organs, such as brown fat (Himms-Hagen, 1985b). Fasting and/or caloric restriction, however, represses activity of the SNS to most tissues (Young and Landsberg, 1976), except white adipose tissue (WAT), in which SNS activity is activated (Migliorini et al., 1997; Rayner, 2001). NE released from the SNS synapses in WAT bind primarily the $\beta 3-\mathrm{AR}$.

In WAT, activation of the $\beta 3-\mathrm{AR}$ induces lipolysis and leads to inhibition of leptin release (Young and Landsberg, 1976; Mantzoros et al., 1996; Giacobino, 1997). Importantly, the initiation of torpor requires leptin levels to be low (Geiser et al., 1998; Gavrilova et al., 1999; Freeman et al., 2004). In fact, both $o b / o b$ mice missing the leptin gene and $d b / d b$ mice missing the leptin receptor can spontaneously enter torpor under fed conditions (Webb et al., 1982; Himms-Hagen, 1985a). Our data then suggest that $D b h-/-$ mice cannot enter torpor during fasting because they cannot suppress leptin secretion in response to the fast (Fig. 4), because they lack stimulation of WAT by NE from the SNS. By re-establishing activation of the $\beta 3$-AR during a fast in $D b h-/-$ mice with $\mathrm{CL}$ 316243 , suppression of circulating leptin and initiation of torpor were both rescued. Interestingly, whereas injection of either isoproterenol or CL 316243 allowed fasted $D b h-/-$ to enter torpor, only isoproterenol allowed rewarming from the torpor bout (Fig. 2). This is particularly puzzling given that $\beta 3$-mediated NST in brown adipose tissue (BAT) generates heat used to exit the torpid state (Cannon and Nedergaard, 2004). We propose three possible explanations for this phenomenon. First, the effects of isoproterenol on $\beta 3$ receptors may persist long enough to rewarm from torpor hours after administration, whereas CL 316243 may be metabolized too quickly. Second, $\beta 1$ - and/or $\beta 2$-mediated mechanisms (i.e., shivering or NST at other organs) may act in concert with BAT activation to end a torpor bout. Third, the activation of $\beta 3$ receptors have effects other than leptin suppression, and sole activation of these receptors in $D b h-/-$ mice may upset other homeostatic mechanisms necessary for rewarming.

In summary, although low leptin signaling is only permissive for torpor (for example, $o b / o b$ and $d b / d b$ mice are not always in torpor) (Freeman et al., 2004), our data suggest that the specific activation of WAT by the SNS mediated through the $\beta 3$-AR during fasting generates an environment (suppressed circulating leptin) conducive for the initiation of torpor in mice.

\section{References}

Bae HH, Larkin JE, Zucker I (2003) Juvenile Siberian hamsters display torpor and modified locomotor activity and body temperature rhythms in response to reduced food availability. Physiol Biochem Zool 76:858 -867.

Bouthegourd JC, Martin JC, Gripois D, Roseau S, Tome D, Even PC (2004) Fat-depleted CLA-treated mice enter torpor after a short period of fasting. Appetite 42:91-98.

Cannon B, Nedergaard J (2004) Brown adipose tissue: function and physiological significance. Physiol Rev 84:277-359.

Carey HV, Andrews MT, Martin SL (2003) Mammalian hibernation: cellular and molecular responses to depressed metabolism and low temperature. Physiol Rev 83:1153-1181.

Collins S, Surwit RS (2001) The $\beta$-adrenergic receptors and the control of adipose tissue metabolism and thermogenesis. Recent Prog Horm Res 56:309-328.

Döring H, Schwarzer K, Neusslein-Hildesheim B, Schmidt I (1998) Leptin selectively increases energy expenditure of food-restricted lean mice. Int J Obes Relat Metab Disord 22:83-88.

Flier JS (1998) What's in a name? In search of leptin's physiologic role. J Clin Endocrinol Metab 83:1407-1413.

Frederich RC, Löllmann B, Hamann A, Napolitano-Rosen A, Kahn BB, Lowell BB, Flier JS (1995) Expression of $o b$ mRNA and its encoded protein in rodents. Impact of nutrition and obesity. J Clin Invest 96:1658-1663.

Freeman DA, Lewis DA, Kauffman AS, Blum RM, Dark J (2004) Reduced leptin concentrations are permissive for display of torpor in Siberian hamsters. Am J Physiol 287:R97-R103.

Gavrilova O, Leon LR, Marcus-Samuels B, Mason MM, Castle AL, Refetoff S, Vinson C, Reitman ML (1999) Torpor in mice is induced by both leptindependent and -independent mechanisms. Proc Natl Acad Sci USA 96:14623-14628.

Geiser F (2004) Metabolic rate and body temperature reduction during hibernation and daily torpor. Annu Rev Physiol 66:239-274.

Geiser F, Ruf T (1995) Hibernation versus daily torpor in mammals and birds: physiological variables and classification of torpor patterns. Physiol Zool 6:935-966.

Geiser F, Körtner G, Schmidt I (1998) Leptin increases energy expenditure of a marsupial by inhibition of daily torpor. Am J Physiol 275:R1627-R1632.

Giacobino JP (1997) Role of the $\beta 3$-adrenoceptor in the control of leptin expression. Horm Metab Res 28:633-637.

Heldmaier G, Steiger R, Ruf T (1993) Suppression of metabolic rate in hibernation. In: Life in the cold (Carey C, Florant GL, Wunder BA, Horwitz B, eds), pp. 545-548. Boulder, CO: Westview.

Himms-Hagen J (1985a) Food restriction increases torpor and improves brown adipose tissue thermogenesis in ob/ob mice. Am J Physiol 248:E531-E539.

Himms-Hagen J (1985b) Brown adipose tissue metabolism and thermogenesis. Ann Rev Nutr 5:69-94.

Hudson JW, Scott IM (1979) Daily torpor in the laboratory mouse, Mus musculus var. albino. Physiol Zool 52:205-218.

Lyman CP, Willis JS, Malan A, Wang LCH (1982) Hibernation and torpor in mammals and birds. New York: Academic.

Mantzoros CS, Qu D, Frederich RC, Susulic VS, Lowell BB, Martos-Flier E, Flier JS (1996) Activation of $\beta 3$ adrenergic receptors suppresses leptin expression and mediates a leptin-independent inhibition of food intake in mice. Diabetes 4:909-914.

Migliorini RH, Garofalo MA, Kettelhut IC (1997) Increased sympathetic 
activity in rat white adipose tissue during prolonged fasting. Am J Physiol 272:R656-R661.

Murchison C, Zhang X, Zhang W, Ouyang M, Lee A, Thomas S (2004) A distinct role for norepinephrine in memory retrieval. Cell 117:131-143.

Nicholls A (2001) History of UCP1. Biochem Soc Trans 29:751-755.

Rayner VD (2001) The sympathetic nervous system in white adipose tissue regulation. Proc Nutr Soc 60:357-364.

Speakman JR, Rowland A (1999) Preparing for inactivity: how insectivorous bats deposit a fat store for hibernation. Proc Nutr Soc 58:123-131.

Swoap SJ (2001) Altered leptin signaling is sufficient, but not required, for hypotension associated with caloric restriction. Am J Physiol 281:H2473-H2479.

Swoap SJ, Weinshenker D, Palmiter RD, Garber G (2004) $\mathrm{Dbh}^{-/}$mice are hypotensive, have altered circadian rhythms, and have abnormal responses to dieting and stress. Am J Physiol 286:R108-R113.

Thomas S, Matsumoto AM, Palmiter R (1995) Noradrenaline is essential for mouse fetal development. Nature 374:643-646.

Thomas S, Marck B, Palmiter R, Matsumoto A (1998) Restoration of norepinephrine and reversal of phenotypes in mice lacking dopamine $\beta$-hydroxylase. J Neurochem 70:2468-2476.

Wang LCH, Hudson JW, eds (1978) Strategies in cold: natural torpidity and thermogenesis. New York: Academic.

Webb GP, Jagot SA, Jakobson ME (1982) Fasting-induced torpor in Mus musculus and its implication in the use of murine models for human obesity studies. Comp Biochem Physiol A 72:211-219.

Young JB, Landsberg L (1976) Suppression of sympathetic nervous system during fasting. Science 196:1473-1475. 